Tropical Journal of Pharmaceutical Research July 2019; 18 (7): 1449-1454

ISSN: $1596-5996$ (print); 1596-9827 (electronic)

(C) Pharmacotherapy Group, Faculty of Pharmacy, University of Benin, Benin City, 300001 Nigeria.

Available online at http://www.tjpr.org

Original Research Article

http://dx.doi.org/10.4314/tjpr.v18i7.12

\title{
Lactobacillus rhamnosus confers protection against colorectal cancer in rats
}

\author{
Jian Huang ${ }^{1 \star}$, Dan Wang ${ }^{2}$, Anye Zhang ${ }^{1}$, Qinglian Zhong ${ }^{1}$, Qun Huang ${ }^{1}$ \\ ${ }^{1}$ Department of Gastroenterology, The Eighth Affiliated Hospital, Sun Yat-Sen University, Shenzhen 518033, Guangdong \\ Province, ${ }^{2}$ Department of Anesthesiology, Ganzhou People's Hospital, The Ganzhou Hospital Affiliated to Nanchang University, \\ Ganzhou 341000, Jiangxi Province, China
}

*For correspondence: Email: BLeogour@yahoo.com; Tel: 0086-0755-83982222

Sent for review: 2 February 2019

Revised accepted: 24 June 2019

\begin{abstract}
Purpose: To investigate the protective effect and mechanism of action of Lactobacillus rhamnosus against colorectal cancer (CRC).

Methods: A total of 40 healthy female Sprague Dawley rats weighing $100-140 \mathrm{~g}$ (mean weight $=120$ $\pm 20 \mathrm{~g})$ were used for this study. The rats were randomly assigned to four groups of 10 rats each: normal control group, L. rhamnosus group; 1, 2-dimethylhydrazine (DMH) group and treatment group. Rats in L. rhamnosus group were inoculated with L. rhamnosus $\left(1 \times 10^{8} \mathrm{CFU} / \mathrm{mL}\right)$ orally for 20 weeks, while rats in $D M H$ group received $35 \mathrm{mg} \mathrm{DMH/kg} /$ week intraperitoneally for 10 weeks for induction of CRC. Treatment group rats received $35 \mathrm{mg} \mathrm{DMH/kg} \mathrm{bwt} \mathrm{intraperitoneally} \mathrm{for} 10$ weeks for induction of CRC, and were treated with L. rhamnosus $\left(1 \times 10^{8} \mathrm{CFU} / \mathrm{mL}\right)$ orally for 20 weeks. After 20 weeks, the rats were euthanized using ether anesthesia. Expressions of inflammatory, angiogenesis and proapoptotic genes were determined using Western blotting and real-time quantitative polymerase chain reaction ( $q R T-P C R)$.

Results: Treatment with $L$. rhamnosus significantly reduced the incidence of $C R C$ in the rats $(p<0.05)$. The incidence of multiple tumors in the treatment group was also significantly reduced, when compared to $\mathrm{DMH}$ group $(p<0.05)$. The protein expressions of inducible nitric oxide synthase (iNOS), tumor necrosis factor a (TNF- $\alpha$ ), nuclear factor kappa-light-chain-enhancer of activated $B$ cells (NF-kB), cyclooxygenase-2 (COX-2), bcl-2 and vascular endothelial growth factor a (VEGF- $\alpha$ ) were significantly upregulated in DMH group, when compared with normal control group $(p<0.05)$. However, treatment with $L$. rhamnosus significantly down-regulated the expressions of these proteins $(p<0.05)$. DMH treatment also significantly upregulated the expressions of iNOS, TNF- $\alpha$, VEGF- $\alpha, N F-k B, \beta-c a t e n i n$ and bax genes $(p<0.05)$. However, $L$. rhamnosus significantly reversed the effects of $D M H$ on the expression levels of these genes $(p<0.05)$.

Conclusion: These results show that $L$. rhamnosus prevents $C R C$ via suppression of expressions of inflammatory and angiogenesis genes, and upregulation of apoptotic gene expression.
\end{abstract}

Keywords: Colorectal cancer, Lactobacillus rhamnosus, Probiotics, Angiogenesis, Expression

This is an Open Access article that uses a fund-ing model which does not charge readers or their institutions for access and distributed under the terms of the Creative Commons Attribution License (http://creativecommons.org/licenses/by/4.0) and the Budapest Open Access Initiative (http://www.budapestopenaccessinitiative.org/read), which permit unrestricted use, distribution, and reproduction in any medium, provided the original work is properly credited.

Tropical Journal of Pharmaceutical Research is indexed by Science Citation Index (SciSearch), Scopus, International Pharmaceutical Abstract, Chemical Abstracts, Embase, Index Copernicus, EBSCO, African Index Medicus, JournalSeek, Journal Citation Reports/Science Edition, Directory of Open Access Journals (DOAJ), African Journal Online, Bioline International, Open-J-Gate and Pharmacy Abstracts 


\section{INTRODUCTION}

Colorectal cancer (CRC) is the third most common cancer and the fourth leading cause of cancer-related deaths worldwide. In 2012 alone, it accounted for about 1.4 million new cases and 0.7 million deaths [1]. Colorectal cancer is expected to increase up to $60 \%$ globally by 2030, with more than 2.2 million new cases and 1.1 million deaths [2]. In 2012, the incidence of CRC was put at 253,000 , accounting for 139,000 deaths in China [3]. The disease is treated using chemotherapy and radiotherapy. However, these treatments do not prevent recurrence, nor do they prolong survival [4].

In recent times, the use of diets especially probiotics as therapy has received huge attention [5]. Probiotics are live, non-pathogenic microorganisms that can be consumed as dietary supplements. They confer beneficial effects on the host by improving intestinal microbial balance. Within the gastrointestinal tract (GIT), the overgrowth of pathogenic microorganisms stimulates intestinal immunity-producing components that may be associated with increased risk of cancer development $[6,7]$. These microorganisms (probiotics), through different processes promote reduction of cancer risk. Thus, the replacement of pathogenic bacteria by probiotics restricts microbial overgrowth in the GIT and modulates the severity of the disease.

At present, most of the available probiotics contain lactic acid bacteria including Lactobacillus and Bifidobacterium species. These probiotics help to maintain intestinal microbial balance, decrease pathogenic bacteria inside the gut flora, improve bowel movement and restore gut microbiota in antibioticassociated diarrhea. The use of probiotics as dietary supplements in the prevention of CRC has been reported [5,8-10]. However, the exact mechanism of cancer prevention by probiotics remains unknown, although some mechanisms have been proposed. These include carcinogen binding and degradation, stimulation of protective enzymes, production of anti-mutagenic compounds, prevention of DNA damage, and activation of local immune response [5].

In the last five decades, Lactobacillus rhamnosus GG strain has been used for the treatment of various GIT abnormalities, including CRC. This bacterium decreases the risk of CRC through several mechanisms such as modulation of gut microbiota, modulation of human dendritic cells, inhibition of harmful enzymatic activities, and production of pro-inflammatory effects.
Colorectal cancer (CRC) is a complex process involving various events which lead to the formation of lesions at molecular, cellular and morphological levels. Inflammation/lesion is the hallmark of cancer and involves the interplay of various inflammatory genes. The nuclear factor kappa $\mathrm{B}\left(\mathrm{NF}_{-\mathrm{k}} \mathrm{B}\right)$, an inflammatory gene was first detected in patients with leukemia, lymphoma, colon cancer, pancreatic cancer, oral cancer and breast cancer. The cyclooxygenase-2 (COX-2) gene has also been shown to be associated with the development and progression of CRC. Other inflammatory cytokines that may be involved in the pathogenesis of CRC include iNOS, TNF- $\alpha$ and VEGF- $\alpha$. The oncogene, bcl-2 and tumor suppressor gene, p53 are associated with cell proliferation and apoptosis [11]. The present study investigated the protective effect of Lactobacillus rhamnosus against CRC, and the underlying mechanism(s).

\section{EXPERIMENTAL}

\section{Materials}

Peroxidase-labeled secondary antibody, cDNA synthesis kit, total RNA purification kit, and primers of iNOS, TNF- $\alpha$, VEGF- $\alpha, N_{-k} B$, COX-2, $\mathrm{bcl}-2$, and $\beta$-actin were products of SigmaAldrich (USA). Image J software was purchased from the National Institute of Health (USA). NanoDrop spectrophotometer was purchased from Thermo Fischer Scientific Co., Ltd. (USA). Flex RT-PCR System was obtained from Applied Biosystems.

\section{Bacterial strain}

Lactobacillus rhamnosus GG 1.2134 (LGG) was obtained from China General Microbiological Culture Center (CGMCC 1.2134). The strain was grown in de Man-Rogosa-Sharpe (MRS) broth, and cells in logarithmic growth phase were selected and used in this study. The cells were centrifuged at $5000 \mathrm{~g}$ for $10 \mathrm{~min}$ at $4{ }^{\circ} \mathrm{C}$, and washed with sterile phosphate-buffered saline (PBS, pH 7.2). Then, the pelleted cells were diluted to a concentration of $10^{8} \mathrm{CFU} / \mathrm{mL}$.

\section{Rats}

A total of 40 healthy female Sprague Dawley rats weighing $100-140 \mathrm{~g}$ (mean weight $=120 \pm 20$ g) were obtained from The Eighth Affiliated Hospital, Sun Yat-Sen University, Shenzhen, Guangdong Province, China. The rats were maintained in polypropylene cages (2 - 3 rats per cage) in a well-ventilated room. Prior to the initiation of the study, the rats were acclimatized to the environment for one week under controlled 
conditions at a temperature of $23 \pm 2{ }^{\circ} \mathrm{C}$, humidity of $55-65 \%$, and $12 \mathrm{~h}$ light/2h dark cycle. They were allowed access to standard rat feed and clean drinking water. The study protocol was approved by the Eighth Affiliated Hospital Animal Care and Use Committee (XY2017-15). The study lasted 20 weeks.

\section{Experimental design}

The rats were randomly assigned to four groups of 10 rats each: normal control group, $L$. rhamnosus group, DMH group and treatment group. Rats in $L$. rhamnosus group were inoculated with $L$. rhamnosus $\left(1 \times 10^{8} \mathrm{CFU} / \mathrm{mL}\right)$ orally for 20 weeks, while $\mathrm{DMH}$ group received $35 \mathrm{mg} \mathrm{DMH} / \mathrm{kg}$ bwt/week intraperitoneally for 10 weeks for induction of CRC. Rats in the treatment group received $35 \mathrm{mg} \mathrm{DMH} / \mathrm{kg}$ bwt intraperitoneally for 10 weeks for CRC induction, and were treated with $L$. rhamnosus $\left(1 \times 10^{8}\right.$ $\mathrm{CFU} / \mathrm{mL}$ ) orally for 20 weeks. After 20 weeks, the rats were euthanized using ether anesthesia and colon tissues were excised for analysis.

\section{Western blotting}

About $100 \mathrm{mg}$ of the colon tissue from each euthanized rat was homogenized in ice-cold Trismannitol buffer (pH 7.2) using mechanical homogenizer until total disruption was achieved. Then, the homogenate was centrifuged at 10,000 $\mathrm{g}$ for $10 \mathrm{~min}$ at $4{ }^{\circ} \mathrm{C}$. The resultant supernatant was collected and kept at $-40{ }^{\circ} \mathrm{C}$ until when required. Protein concentration was determined using Bradford method [13]. A portion of total tissue protein $(10 \mu \mathrm{g})$ from each sample was separated on a $12 \%$ sodium dodecyl sulphate (SDS)-polyacrylamide gel electrophoresis and transferred to a fixed polyvinylidene fluoride membrane at $110 \mathrm{~V}$ and $90{ }^{\circ} \mathrm{C}$ for $120 \mathrm{~min}$. Subsequently, non-fat milk powder (5\%) in Trisbuffered saline containing $0.2 \%$ Tween-20 (TBS$\mathrm{T})$ was added with gentle shaking at $37{ }^{\circ} \mathrm{C}$ and incubated to block non-specific binding of the blot [14].

Incubation of the blots was performed overnight at $4{ }^{\circ} \mathrm{C}$ with primary antibodies of rabbit polyclonal anti- iNOS (1:500), TNF- $\alpha$ (1:2000), VEGF- $\alpha \quad(1: 2000), \quad N F-_{k} B \quad(1: 500), \quad$ COX-2 $(1: 2000)$, $\beta$-actin $(1: 5000)$ and bcl-2 (1:2000). Then, the membrane was washed thrice with TBS-T and further incubated with horseradish peroxidase-conjugated goat anti-rabbit IgG secondary antibody for $3 \mathrm{~h}$ at room temperature. The blot was developed using an X-ray film. Then, diaminobenzidine (DAB, $10 \mathrm{mg} / 15 \mathrm{~mL}$ of PBS with $15 \mu \mathrm{L} \quad \mathrm{H}_{2} \mathrm{O}_{2}$ ) was added to the membrane in the dark till the protein band developed to the required intensity. Immediately after the band reached the required intensity, the membrane was washed with Milli-Q water and air-dried. Using image $\mathrm{J}$ software, the bands obtained were visualized and analyzed. The density was expressed as gray values in densitrometric units. The respective protein expression levels were normalized to that of $\beta$ actin which was used as a standard.

\section{cDNA synthesis and quantitative Real-Time PCR (qRT-PCR)}

Colon tissue was extracted using GenElute ${ }^{\mathrm{TM}}$ total RNA purification kit to obtain mRNA. The concentration and purity of the extracted RNA was determined spectrophotometrically at 260/280 nm. The RNA was reverse-transcribed to cDNA using First Strand cDNA synthesis kit. The qRT-PCR was performed using QuantStudio $^{\mathrm{TM}} 7$ Flex Real-Time PCR System. The PCR cycling conditions were: initial denaturation at $95{ }^{\circ} \mathrm{C}$ for $30 \mathrm{sec}$, followed by 40 cycles of $95{ }^{\circ} \mathrm{C}$ for $30 \mathrm{sec}, 55^{\circ} \mathrm{C}$ for $30 \mathrm{sec}$ and extension at $72{ }^{\circ} \mathrm{C}$ for $1 \mathrm{~min}$. Dissociation meltcurve analysis was performed to determine nonspecific amplification. The mean threshold value for each cycle was normalized to the expression of $\beta$-actin. The relative expression of RNA was calculated using 2- $\Delta \Delta \mathrm{Ct}$ method. The primer sequences used are shown in Table 1.

Table 1: Primers sequences used for gene expression

\begin{tabular}{|c|c|}
\hline Gene & Primer sequence 5'-3' \\
\hline $\begin{array}{l}\beta- \\
\text { Catenin }\end{array}$ & $\begin{array}{l}\text { 5'- ACTGGCAGCAGCAATCTTAC-3' } \\
\text { 5'- GAGGTGTCCACATCTTCTTC-3' }\end{array}$ \\
\hline TNF- $\alpha$ & $\begin{array}{l}\text { 5'- CTTCTGTCTACTGAACTTCG-3' } \\
\text { 5'- AAGATGATCTGAGTGTGAGG-3' }\end{array}$ \\
\hline$N F-k b$ & $\begin{array}{l}\text { 5'-GCTTACGGTGGGATTGCATT-3' } \\
\text { 5'-TTATGGTGCCATGGGTGATG-3' }\end{array}$ \\
\hline iNOS & $\begin{array}{l}\text { 5'-TAAAGGGACAGCGTCAGCGA-3' } \\
\text { 5'-TGGGGGAACACAGTAATGGC-3' }\end{array}$ \\
\hline Bax & $\begin{array}{l}\text { 5'- GGCGAATTGGAGATGAACTG-3' } \\
\text { 5'- CCCCAGTTGAAGTTGCCAT-3' }\end{array}$ \\
\hline $\begin{array}{l}\text { VEGF- } \\
\alpha\end{array}$ & $\begin{array}{l}\text { 5'-TATATCTTCAAGCCGTCCTGTG-3' } \\
\text { 5'-TCTCCTATGTGCTGGCTTTG-3' }\end{array}$ \\
\hline$\beta$-actin & $\begin{array}{l}\text { 5'-TGT TTG AGA CCT TCA ACA CC-3' } \\
\text { 5'-TAG GAG CCA GGG CAG TAA TC-3' }\end{array}$ \\
\hline
\end{tabular}

\section{Statistical analysis}

Data are expressed as mean \pm SEM, and the statistical analysis was performed using SPSS (13.0). Groups were compared using Student $t$ tests. Values of $p<0.05$ were considered statistically significant. 


\section{RESULTS}

\section{Outcome of CRC induction}

Treatment with $L$. rhamnosus significantly reduced the incidence of $C R C$ in the rats $(p<$ 0.05). The incidence of multiple tumors in the treatment group was also significantly reduced, when compared with DMH group $(p<0.05)$. These results are shown in Table 2.

Table 2: Incidence of CRC among the groups

\begin{tabular}{lcc}
\hline $\begin{array}{l}\text { Group } \\
\mathbf{n}\end{array}$ & $\begin{array}{c}\text { Number of rats } \\
\text { with tumor }\end{array}$ & $\begin{array}{c}\text { Number of rats } \\
\text { with multiple } \\
\text { tumors }\end{array}$ \\
\hline $\begin{array}{l}\text { Normal } \\
\text { control } 10\end{array}$ & $0(0.00 \%)$ & $0(0.00 \%)$ \\
L. rhamnosus & $0(0.00 \%)$ & $0(0.00 \%)$ \\
10 & $10(100 \%)$ & $7(70 \%)$ \\
$D M H 10$ & $6(60 \%)$ & $2(20 \%)$ \\
Treatment 10 & P & \\
\hline$P<0.05$, when compared with $D M H$ group
\end{tabular}

Expressions of inflammation- and
angiogenesis-related proteins

The protein expressions of iNOS, TNF- $\alpha, N_{-k} B$, COX-2, bcl-2 and VEGF- $\alpha$ were significantly upregulated in $\mathrm{DMH}$ group, when compared with normal control group $(p<0.05)$. However, treatment with $L$. rhamnosus significantly downregulated the expression of these proteins $(p<$ 0.05 ; Figure 1).
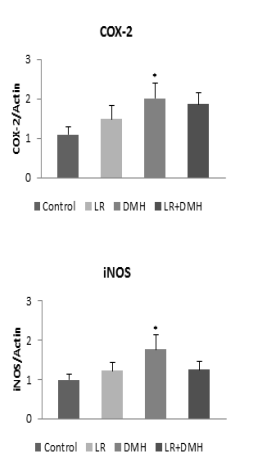

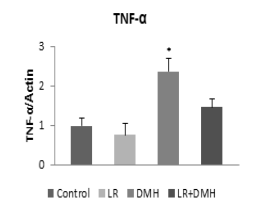

BCL

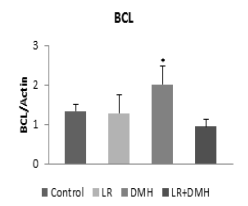

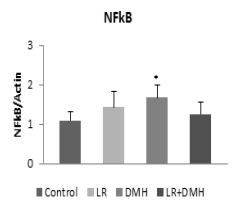

VEGF

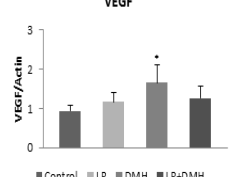

Figure 1: Protein expressions among the groups. ${ }^{*} P<$ 0.05 , when compared with normal control group

\section{Levels of expression of inflammation- and angiogenesis-related genes}

The expressions of iNOS, TNF- $\alpha$, VEGF- $\alpha$, NF${ }_{k} B$ and $\beta$-catenin genes were significantly upregulated by $\mathrm{DMH}(p<0.05)$. In contrast, the expression of the pro-apoptotic gene, bax, was significantly down-regulated by $\mathrm{DMH}(p<0.05)$. However, treatment with $L$. rhamnosus significantly reversed the effects of $\mathrm{DMH}$ on the expression levels of these genes $(p<0.05$; Figure 2).
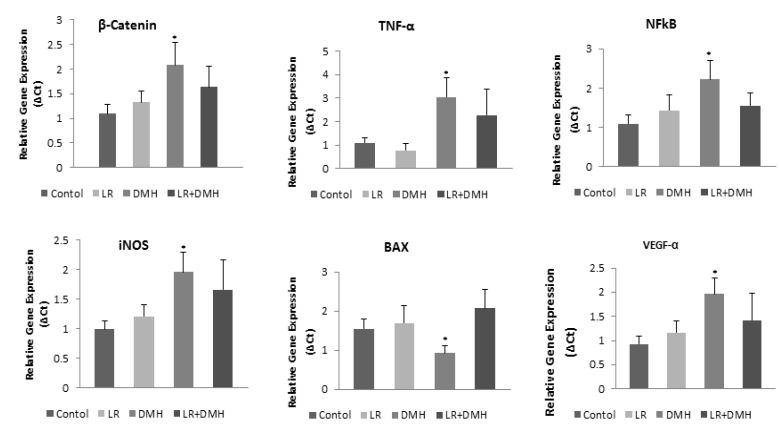

Figure 2: Gene expressions among the groups. ${ }^{*} P<$ 0.05 , when compared with normal control group

\section{DISCUSSION}

Colorectal cancer is one of the most dreadful tumors due to the fact that it is characterized by high morbidity and mortality. The use of probiotics has shown promising potential in the treatment of colorectal and other cancers. Dimethylhydrazine is a carcinogenic agent used to induce CRC with similar morphological and anatomical features as human colonic neoplasm [5-8]. Metabolites of DMH are highly specific, indirect carcinogens that produce CRC in a dosedependent manner.

The doses of DMH and L. rhamnosus used in this study were obtained from literature $[5,15]$. The results of this study showed that treatment with $L$. rhamnosus significantly reduced the incidence of CRC in the rats. The incidence of multiple tumors in the treatment group was also significantly reduced, when compared with the $\mathrm{DMH}$ group. These results suggest that $L$. rhamnosus may be effective in reducing the incidence of tumor and its multiplicity, and are in agreement with those previously reported $[5,16]$.

The mechanism by which probiotics prevent the development of cancer has not been fully elucidated. The $\mathrm{NF}_{-\mathrm{k}} \mathrm{B}$ is associated with proinflammatory response. This molecule mediates inflammatory response via induction of downstream cytokines such as iNOS, TNF- $\alpha$ and COX-2 [17]. Angiogenesis plays a vital role in the development of tumor and its progression.

In the present study, the expressions of $\mathrm{NF}_{-\mathrm{k}} \mathrm{B}$ protein and gene were significantly higher in $\mathrm{DMH}$ group than in the treatment group, and are in agreement with those previously reported [15]. The increased level of expression of $\mathrm{NF}_{-k} \mathrm{~B}$ was directly linked to increased expressions of iNOS, COX-2 and TNF- $\alpha$ in the DMH group. Increased 
expression of COX-2 is associated with incidence of $\mathrm{CRC}$, and altered COX-2 activity may reduce incidence of intestinal tumorigenesis.

The anti-inflammatory effect of $L$. rhamnosus is exerted via attenuation of the expressions of TNF- $\alpha$ and NF-k $[18,19]$. The reduced expressions of $\mathrm{NF}_{-\mathrm{k}} \mathrm{B}$ pathway proteins in the treatment group suggest that $L$. rhamnosus may be effective in preventing $\mathrm{CRC}$. Therefore, a possible mechanism by which probiotics prevent development of $\mathrm{CRC}$ is by targeting the $\mathrm{NF}_{-\mathrm{k}} \mathrm{B}$ pathway. The enzyme COX-2 is activated during inflammation, and it promotes angiogenesis via stimulation of VEGF- $\alpha$ expression [20,21]. Angiogenesis, the formation of new blood vessels is an important process responsible for tumor growth and depends on TNF- $\alpha$ and VEGF$\alpha$. Another downstream cytokine of $\mathrm{NF}_{-k} \mathrm{~B}$ is VEGF- $\alpha$.

In this study, the expression of VEGF- $\alpha$ was upregulated in the $D M H$ group, when compared with normal control group. However, treatment with $L$. rhamnosus significantly suppressed the expression of $\mathrm{NF}_{-k} \mathrm{~B}$ and its downstream cytokines. Studies have shown that increased expression of $\mathrm{NF}_{-\mathrm{k}} \mathrm{B}$ is associated with increased levels of COX-2, VEGF and TNF- $\alpha$ [17]. These results suggest that $\mathrm{NF}_{-\mathrm{k}} \mathrm{B}$ downstream cytokines may be involved in the development of CRC, and are not in agreement with those reported in a previous study [22]. Apoptosis is a major antitumor process, and its deregulation is associated with cancer.

In this study, L. rhamnosus significantly increased the expression of the pro-apoptotic gene, bax, and significantly reduced its protein expression. Treatment with $L$. rhamnosus has been shown to induce apoptosis via activation of bax and suppression of bcl-2 [23]. Probiotics have been shown to upregulate bax protein expression and restore the normal expression of bcl-2 [5]. In the present study, the increased expression of bax and suppression of bcl-2 expression in the treatment group is an indication that the positive association between $L$. rhamnosus and epithelial cell apoptosis may be responsible for its anti-cancer effect. The inflammatory cytokine TNF- $\alpha$ induces the upregulation of bcl-2, an anti-apoptotic protein, and activates the survival pathway, thereby enabling cells to escape apoptosis [24].

The reduced expression of TNF- $\alpha$ in the treatment group suggests that the anticancer effect of L. rhamnosus may be exerted through induction of apoptosis and evasion of cell apoptosis. The cytokine TNF- $\alpha$ is associated with intra-mucosal and invasive CRC [25,26]. The tumor progression gene, $\beta$-catenin is involved in the pathogenesis of CRC. In this study, $\beta$-catenin gene expression was significantly higher in $\mathrm{DMH}$ group than in the treatment group, which is in agreement with those previously reported [15].

\section{CONCLUSION}

These results show that $L$. rhamnosus prevents the development of CRC via suppression of expressions of inflammatory and angiogenesis genes, and upregulation of apoptotic gene expression.

\section{DECLARATIONS}

\section{Conflict of interest}

No conflict of interest is associated with this work.

\section{Contribution of authors}

We declare that this work was done by the authors named in this article and all liabilities pertaining to claims relating to the content of this article will be borne by the authors.

\section{Open Access}

This is an Open Access article that uses a funding model which does not charge readers or their institutions for access and distributed under the terms of the Creative Commons Attribution License (http://creativecommons.org/licenses/by/ 4.0) and the Budapest Open Access Initiative (http://www.budapestopenaccessinitiative.org/rea d), which permit unrestricted use, distribution, and reproduction in any medium, provided the original work is properly credited.

\section{REFERENCES}

1. Arnold M, Sierra MS, Laversanne M, Soerjomataram I, Jemal A, Bray F. Global patterns and trends in colorectal cancer incidence and mortality. Gut. 2017; 66(4): 683-691.

2. Ferlay J SI, Ervik M, et al., editor GLOBOCAN 2012 v1.0, Cancer Incidence and Mortality Worldwide: IARC Cancer Base No. 11. International Agency for Research on Cancer; 2013; Base No. 11. Lyon, France.

3. Gu MJ, Huang QC, Bao CZ, Li YJ, Li XQ, Ye D, Ye ZH, Chen K, Wang JB. Attributable causes of colorectal cancer in China. BMC Cancer. 2018; 18: 38.

4. Martenson JA Jr, Willett CG, Sargent DJ, Mailliard JA, Donohue JH, Gunderson LL, Thomas CR Jr, Fisher B, Benson $A B$ 3rd, Myerson $R$, et al. Phase III study of 
adjuvant chemotherapy and radiation therapy compared with chemotherapy alone in the surgical adjuvant treatment of colon cancer: results of intergroup protocol 0130. J Clin Oncol. 2004; 22(16): 3277 - 3283.

5. Walia S, Kamal R, Dhawan DK, Kanwar SS. Chemoprevention by Probiotics During 1,2Dimethylhydrazine-Induced Colon Carcinogenesis in Rats. Digest Dis Sci. 2018; 63(4): 900 - 909.

6. Alizadeh AM, Afrouzan $H$, Dinparast-Djadid N, Sawaya AC, Azizian S, Hemmati HR, Mohagheghi MA, Erfani S et al. Chemoprotection of MNNG-initiated gastric cancer in rats using Iranian propolis. Arch Iran Med. 2015; 18(1): 18 - 23.

7. Davis CD, Milner JA. Gastrointestinal microflora, food components and colon cancer prevention. I Nutr Biochem. 2009; 20(10): 743 - 752.

8. Femia $A P$, Luceri $C$, Dolara $P$, Giannini A, Biggeri $A$, Salvadori M, Clune Y, Collins KJ, Paglierani M, Caderni G. Antitumorigenic activity of the prebiotic inulin enriched with oligofructose in combination with the probiotics Lactobacillus rhamnosus and Bifidobacterium lactis on azoxymethane-induced colon carcinogenesis in rats. Carcinogenesis. 2002; 23(11): 1953 - 1960.

9. Kassayova M, Bobrov N, Strojny L, Kiskova T, Mikes J, Demeckova $V$, Orendáš $P$, Bojková $B$, Péč $M$, Kubatka $P$, et al. Preventive effects of probiotic bacteria Lactobacillus plantarum and dietary fiber in chemicallyinduced mammary carcinogenesis. Anticancer Res. 2014; 34(9): 4969 - 4975.

10. Ni Y, Wong VH, Tai WC, Li J, Wong WY, Lee MM, Fong FL, El-Nezami H, Panagiotou G. A metagenomic study of the preventive effect of Lactobacillus rhamnosus GG on intestinal polyp formation in $\mathrm{Apc}(\mathrm{Min} /+)$ mice. J Appl Microbiol. 2017; 122(3): 770 - 784.

11. Brenner DR, Scherer D, Muir K, Schildkraut J, Boffetta $P$, Spitz MR, Le Marchand L, Chan AT, Goode EL, Ulrich $C M$ et al. A review of the application of inflammatory biomarkers in epidemiologic cancer research. Cancer epidemiology, biomarkers \& prevention: a publication of the American Association for Cancer Research, cosponsored by the American Society of Preventive Oncology. 2014; 23(9): 1729 - 1751.

12. Zhu Q, Jin Z, Wu W, Gao R, Guo B, Gao Z, Yang Y, Qin $H$. Analysis of the intestinal lumen microbiota in an animal model of colorectal cancer. PloS One. 2014; 9(6): e90849.

13. Bradford MM. A rapid and sensitive method for the quantitation of microgram quantities of protein utilizing the principle of protein-dye binding. Analytical Biochem. 1976; 72: 248 - 254.

14. Laemmli UK. Cleavage of structural proteins during the assembly of the head of bacteriophage T4. Nature. 1970; 227(5259): 680 - 685.

15. Gamallat $Y$, Meyiah A, Kuugbee ED, Hago AM, Chiwala $G$, Awadasseid A, Bamba D, Zhang $X$, Shang $X$, Luo $F$ et al. Lactobacillus rhamnosus induced epithelial cell apoptosis, ameliorates inflammation and prevents colon cancer development in an animal model. Biomed Pharmacother. 2016; 83: 536 - 541.

16. Le Leu RK, Hu Y, Brown IL, Woodman RJ, Young GP. Synbiotic intervention of Bifidobacterium lactis and resistant starch protects against colorectal cancer development in rats. Carcinogenesis. 2010; 31(2): 246 251.

17. Huang $S$, DeGuzman A, Bucana $C D$, Fidler IJ. Nuclear factor-kappaB activity correlates with growth, angiogenesis, and metastasis of human melanoma cells in nude mice. Clin Cancer Res. 2000; 6(6): 2573 - 2581.

18. Iyer $C$, Kosters $A$, Sethi G, Kunnumakkara AB, Aggarwal $B B$, Versalovic J. Probiotic Lactobacillus reuteri promotes TNF-induced apoptosis in human myeloid leukemia-derived cells by modulation of NF-kappaB and MAPK signalling. Cellular Microbiol. 2008; 10(7): 1442 1452.

19. Lee DK, Jang S, Baek EH, Kim MJ, Lee KS, Shin HS, Chung MJ, Kim JE, Lee KO, Ha NJ. Lactic acid bacteria affect serum cholesterol levels, harmful fecal enzyme activity, and fecal water content. Lipids Health Dis. 2009; 8: 21.

20. Sharma-Walia N, Paul AG, Bottero V, Sadagopan S, Veettil MV, Kerur N, Chandran B. Kaposi's sarcoma associated herpes virus (KSHV) induced COX-2: a key factor in latency, inflammation, angiogenesis, cell survival and invasion. PLoS Pathogens. 2010; 6(2): e1000777.

21. Sappayatosok K, Maneerat $Y$, Swasdison S, Viriyavejakul $P$, Dhanuthai K, Zwang J, Chaisri U. Expression of proinflammatory protein, iNOS, VEGF and COX-2 in oral squamous cell carcinoma (OSCC), relationship with angiogenesis and their clinico-pathological correlation. Medicina Oral, Patologia Oral Y Cirugia Bucal. 2009; 14(7): E319 - E324.

22. Khailova L, Petrie B, Baird $\mathrm{CH}$, Dominguez Rieg JA, Wischmeyer PE. Lactobacillus rhamnosus $G G$ and Bifidobacterium longum attenuate lung injury and inflammatory response in experimental sepsis. PloS One. 2014; 9(5): e97861.

23. Wu S, Yuan L, Zhang Y, Liu F, Li G, Wen K, Kocher J, Yang $X$, Sun J. Probiotic Lactobacillus rhamnosus GG mono-association suppresses human rotavirus-induced autophagy in the gnotobiotic piglet intestine. Gut Pathogens. 2013; 5(1): 22.

24. Pikarsky E, Porat RM, Stein I, Abramovitch R, Amit S, Kasem S, Gutkovich-Pyest E, Urieli-Shoval S, Galun E, Ben-Neriah Y. NF-kappaB functions as a tumour promoter in inflammation-associated cancer. Nature. 2004; 431(7007): 461 - 466.

25. Jung YS, Jun S, Lee SH, Sharma A, Park Jl. Wnt2 complements Wnt/beta-catenin signaling in colorectal cancer. Oncotarget. 2015; 6(35): 37257 - 37268.

26. Sadot $E$, Geiger B, Oren M, Ben-Ze'ev A. Downregulation of beta-catenin by activated p53. Mol cellular Biol. 2001; 21(20): 6768 - 6781. 